\title{
Predicting nitrogen requirement in perennial ryegrass seed crops
}

\author{
M.P. ROLSTON ${ }^{1}$, B.L. MCCLOY ${ }^{2}$ and R.J. CHYNOWETH ${ }^{3}$ \\ ${ }^{1}$ AgResearch Lincoln, Private Bag 4749, Christchurch 8140, New Zealand \\ ${ }^{2}$ New Zealand Arable, PO Box 16 101, Christchurch, New Zealand \\ ${ }^{3}$ Foundation for Arable Research, PO Box 80 Lincoln, New Zealand
}

phil.rolston@agresearch.co.nz

\begin{abstract}
Results from 17 nitrogen $(\mathrm{N})$ rate response trials using current best management including the plant growth regulator trinexapac-ethyl (Moddus) were used to predict optimum applied $\mathrm{N}$ rates for perennial ryegrass. The average optimum applied $\mathrm{N}$ rate was $145 \mathrm{~kg} / \mathrm{ha}$. A simple model using late winter soil mineral $\mathrm{N}(0-30$ $\mathrm{cm}$ ) and a total $\mathrm{N}$ requirement (mineral $\mathrm{N}+$ applied N) of $185 \mathrm{~kg} \mathrm{~N} / \mathrm{ha}$ is recommended for growers to predict the applied spring $\mathrm{N}$ rate.
\end{abstract}

Keywords: nitrogen, optimum rate, Lolium perenne, seed yield

\section{Introduction}

In 2004 we identified that many perennial ryegrass (Lolium perenne L.) seed growers were using excessive rates of nitrogen $(\mathrm{N})$, typically $216 \mathrm{~kg} \mathrm{~N} / \mathrm{ha}$ and that ryegrass seed yields were being depressed by the higher $\mathrm{N}$ rates (McCloy \& Rolston 2005). Our trials showed that there was a high economic cost to the farmer when excess $\mathrm{N}$ was applied. Most applied $\mathrm{N}$ to seed crops is in the form of urea. High rates of $\mathrm{N}$, especially as urea, have the potential for environmental costs associated with nitrate leaching, ammonia volatilisation, soil acidification, and a large carbon footprint due to the high energy cost to manufacture urea. Urea costs have doubled in the last two years associated with rising oil and energy prices, increasing from \$NZ 420/T to \$NZ 1100/T (Ballance 2008), making $\mathrm{N}$ application the single most expensive input for seed production.

During the 1980s and 1990s there was a considerable amount of research undertaken on ryegrass seed crop responses to and requirements for $\mathrm{N}$ (Brown 1980a, b; Hampton 1987; Rowarth \& Archie 1995; Rowarth et al. 1998; Cookson et al. 1999; Williams et al. 2001). In 2000 the plant growth regulator (PGR) Moddus (trinexapac-ethyl) was introduced increasing seed yields by $50 \%$ with a near $100 \%$ adoption by ryegrass seed producers (Rolston et al. 2004). Interviews with seed growers indicate that there was a perception that because Moddus reduced lodging, higher $\mathrm{N}$ rates could be used to increase seed yields still further. In the same period, mineral soil $\mathrm{N}$ testing was being adopted as a tool to predict applied $\mathrm{N}$ rates for wheat (Jamieson et al., 2003). Late winter soil $\mathrm{N}$ testing was not generally used in New Zealand for $\mathrm{N}$ use predictions in ryegrass. In winter wheat the soil $\mathrm{N}$ tests commonly sample a 0 to $90 \mathrm{~cm}$ deep profile, although stones restrict depth of sampling to about 60 $\mathrm{cm}$ on many Canterbury soils. Perennial ryegrass sown in autumn has the bulk $(>90 \%)$ of its roots in the 0 to $15 \mathrm{~cm}$ depth range. A decision was made in the trials to sample for mineral $\mathrm{N}$ at 0 to $30 \mathrm{~cm}$. Deeper soil samples $30-60 \mathrm{~cm}$ were collected, and incubation (mineralisable $\mathrm{N}$ ) analysis were undertaken in some trials.

In New Zealand perennial ryegrass seed crops are sown in autumn as a one harvest crop. This is in contrast to Oregon and Europe, two areas that produce large volumes of perennial ryegrass seed, where crops are multi-year harvested and $\mathrm{N}$ rate trials are commonly based on the second production year (Hart et al. 2007). This makes the New Zealand production system unique and highlights the need for New Zealand-based research in perennial ryegrass seed production. 
This paper summarises the results of 17 field trials conducted from 2003 on $\mathrm{N}$ rate responses from perennial ryegrass seed crops managed with Moddus PGR and with known soil mineral $\mathrm{N}\left(\mathrm{NH}_{4}+\mathrm{NO}_{3}\right)$ values and evaluates a simple $\mathrm{N}$ rate prediction.

\section{Methods}

Trials were undertaken in Canterbury (Methven, Ashburton, and Timaru) from 2003 to 2007 in farmer's fields. The trial management inputs (except spring N) were undertaken by the grower and were the same as his field management. The grower inputs include sowing rate and timing, autumn fertiliser, herbicides, grazing and closing date, heavy rolling, fungicides, Moddus PGR and irrigation. The cultivars varied (Table 1) but most were early- to midflowering diploids with various endophyte combinations (data not presented). All sites were autumn sown (March to mid April) and harvested in the first summer. Trials had a nil $\mathrm{N}$ control with either five or six $\mathrm{N}$ rates in $50 \mathrm{~kg} / \mathrm{ha}$ increments, in randomised block designs with four replicates. Plots were 3.2 $\mathrm{m}$ wide and 9.0 to $10 \mathrm{~m}$ long. All sites except Trial 11 were irrigated. Urea $(46 \% \mathrm{~N})$ was applied at closing (late September/early October) and at mid-stem elongation (usually three weeks after the first application) in an equal split rate.

Mineral soil $\mathrm{N}$ (sum of nitrate-N and ammonium- $\mathrm{N}$ calculated on a dry weight basis) for 0 to $30 \mathrm{~cm}$ samples taken in late winter (end August/early September), frozen and was analysed at a commercial laboratory based on a $2 \mathrm{M} \mathrm{KCl}$ extraction with nitrate- $\mathrm{N}$ determined by cadmium reduction and N-(1naphthyl) ethylenediamine dihydrochloride (NED) colorimetry; and ammonia- $\mathrm{N}$ by Berthelot colorimetry. Crop bulk at harvest was assessed from a $0.25 \mathrm{~m}^{2}$ quadrant. At harvest seed and straw samples were collected and the $\mathrm{N}$ content determined at a commercial laboratory using an estimated N\% by Near Infrared Spectrometry (NIRS) with a calibration based on $\mathrm{N}$ by Dumas combustion. Above ground $\mathrm{N}$ uptake $(\mathrm{kg} / \mathrm{ha})$ by the crop was calculated as straw mass $(\mathrm{kg} / \mathrm{ha}) \times$ straw $\mathrm{N}$ concentration $(\mathrm{g} / \mathrm{kg})+$ seed mass $(\mathrm{kg} / \mathrm{ha}) \mathrm{x}$ seed $\mathrm{N}$ concentration $(\mathrm{g} / \mathrm{kg})$.

At harvest the trial was windrowed on the same day or the day after the farmer windrowed the field at ca. 38 to $40 \%$ seed moisture content. A $1.7 \mathrm{~m}$ wide swath by the full plot length was cut in each plot with a modified plot windrower. The trial was harvested using a plot combine the day the farmer combined. This was 7 to 10 days after windrowing. The seed was machine dressed to a First Generation Seed Certification purity standard (MAF 2006) and seed yield calculated at $12 \%$ seed moisture content.

Data were analysed using GenStat (v9) (Payne et al. 2007). The optimum N rate was calculated using both a polynomial model and a linear-plateau model (a conservative model where the optimum was the least value not significantly different from the highest seed yield value). The total $\mathrm{N}$ was calculated as the combined applied $\mathrm{N}+$ mineral $\mathrm{N}(0-30 \mathrm{~cm})$. Economic analysis used 2008 grower prices; seed $(\$ 2.50 / \mathrm{kg}) ; \mathrm{N}$ $(\$ 2.10 / \mathrm{kg} \mathrm{N})$ and application cost of $\$ 20 / \mathrm{ha}$ per application.

\section{Results}

The average soil mineral $\mathrm{N}(0-30 \mathrm{~cm})$ concentration in the trials was $12 \mathrm{mg} / \mathrm{kg}$ soil, equivalent to $41 \mathrm{~kg} \mathrm{~N} / \mathrm{ha}$ with a range from 10 to $122 \mathrm{~kg} \mathrm{~N} / \mathrm{ha}$, with most sites in the range of 30 to $50 \mathrm{~kg} \mathrm{~N} /$ ha (Table 1). In the mineral $\mathrm{N}$ fraction the $\mathrm{NO}_{3}$ and $\mathrm{NH}_{4}$ proportions were 68 and 32\% respectively.

The average seed yield of the nil $\mathrm{N}$ control treatment was $1,590 \mathrm{~kg} / \mathrm{ha}$, and for the optimum $\mathrm{N}$ treatment $2,170 \mathrm{~kg} / \mathrm{ha}$, a $43 \%$ yield increase (Table 1).

The average optimum applied $\mathrm{N}$ for the 17 trials was $143 \mathrm{~kg} \mathrm{~N} / \mathrm{ha}$ (range 70 to $240 \mathrm{~kg}$ $\mathrm{N} / \mathrm{ha}$ ) (Table 1). An example of a linearplateau response with an optimum applied $\mathrm{N}$ of $117 \mathrm{~kg} / \mathrm{ha}$ is shown in Figure 1. This trial 
had a mineral $\mathrm{N}(0-30 \mathrm{~cm})$ value of $33 \mathrm{~kg} / \mathrm{ha}$ and a total optimum $\mathrm{N}$ of $150 \mathrm{~kg} / \mathrm{ha}$. For the 17 trials the average total optimum $\mathrm{N}$ value was $184 \mathrm{~kg} \mathrm{~N} /$ ha (Table 1).

The choice of model to predict optimum $\mathrm{N}$ has a large influence on the prediction value. The linear-plateau model predictions are conservative. The linear-plateau model was chosen if the yield response to higher $\mathrm{N}$ rates were not significantly different from each other; and the polynomial response when highest $\mathrm{N}$ rates depressed yields. Both response types were observed, the latter when very high rates of $\mathrm{N}(>250 \mathrm{~kg} \mathrm{~N} / \mathrm{ha})$ were included. For trial 12 the data has a good fit to both a linear-plateau model $\mathrm{R}^{2}=0.95$ (Figure 1) and to a polynomial model $\left(\mathrm{R}^{2}=0.97\right)$ (Figure 2). However the optimum applied $\mathrm{N}$ using the polynomial model is $170 \mathrm{~kg} \mathrm{~N} /$ ha (Figure 2) compared with $117 \mathrm{~kg} / \mathrm{ha}$ in the linear-plateau model (Figure 1).

Table 1 Summary of trials, year, cultivar, mineral $\mathrm{N}\left(\mathrm{NH}_{4}+\mathrm{NO}_{3}\right)$ in the 0 to $30 \mathrm{~cm}$ soil profile, the optimum $\mathrm{N}$ required using linear-plateau model and the seed yield for N0 (nil N) and optimum $\mathrm{N}$ rate. All trials grazed at closing and irrigated unless specified.

\begin{tabular}{|c|c|c|c|c|c|c|c|}
\hline \multirow[b]{2}{*}{ No. } & \multirow[b]{2}{*}{ Year } & \multirow[b]{2}{*}{ Cultivar } & \multirow{2}{*}{$\begin{array}{l}0-30 \mathrm{~cm} \\
\mathrm{Min} N \\
(\mathrm{~kg} / \mathrm{ha})\end{array}$} & \multicolumn{2}{|l|}{ N opt } & N0 & $\mathrm{N}$ opt \\
\hline & & & & $\begin{array}{l}\text { Applied } \\
(\mathrm{kg} / \mathrm{ha})\end{array}$ & $\begin{array}{l}\text { Total } \\
(\mathrm{kg} / \mathrm{ha})\end{array}$ & \multicolumn{2}{|c|}{$\begin{array}{l}\text { Seed Yield } \\
(\mathrm{kg} / \mathrm{ha})\end{array}$} \\
\hline 1 & $2003 / 04$ & Banquet & 46 & 154 & 200 & 1010 & 1710 \\
\hline 2 & $2003 / 04$ & Bronsyn & 50 & 150 & 200 & 1440 & 1820 \\
\hline 3 & $2004 / 05$ & Bronsyn & 71 & 129 & 200 & 1600 & 1970 \\
\hline 4 & $2004 / 05$ & Aries & 29 & 171 & 200 & 1870 & 2030 \\
\hline 5 & $2005 / 06$ & Impact & 36 & 214 & 250 & 1210 & 2050 \\
\hline 6 & $2005 / 06$ & Hillary & 122 & 104 & 226 & 1170 & 1790 \\
\hline 7 & $2006 / 07$ & Bealey & 36 & 164 & 200 & 2170 & 2630 \\
\hline 8 & $2006 / 07$ & Bealey $^{1}$ & 36 & 114 & 150 & 1420 & 2230 \\
\hline 9 & $2006 / 07$ & Bronsyn & 10 & 140 & 150 & 1610 & 2510 \\
\hline 10 & $2006 / 07$ & Bronsyn $^{1}$ & 10 & 240 & 250 & 1100 & 1880 \\
\hline 11 & $2006 / 07$ & Hillary & 33 & 167 & 200 & 1340 & 2240 \\
\hline 12 & $2006 / 07$ & Hillary & 33 & 117 & 150 & 1520 & 2240 \\
\hline 13 & $2006 / 07$ & Commando & 30 & 70 & 100 & 2510 & 2790 \\
\hline 14 & $2007 / 08$ & Hillary & 36 & 114 & 150 & 1590 & 2250 \\
\hline 15 & $2007 / 08$ & Commando & 54 & 144 & 200 & 1810 & 2250 \\
\hline 16 & $2007 / 08$ & Arrow & 30 & 120 & 150 & 1910 & 2340 \\
\hline \multirow[t]{2}{*}{17} & $2007 / 08$ & Arrow $^{1}$ & 30 & 120 & 150 & 1810 & 2230 \\
\hline & AVG & & 41 & 143 & 184 & 1590 & 2170 \\
\hline
\end{tabular}

${ }^{1}$ mown at closing time in late September. 


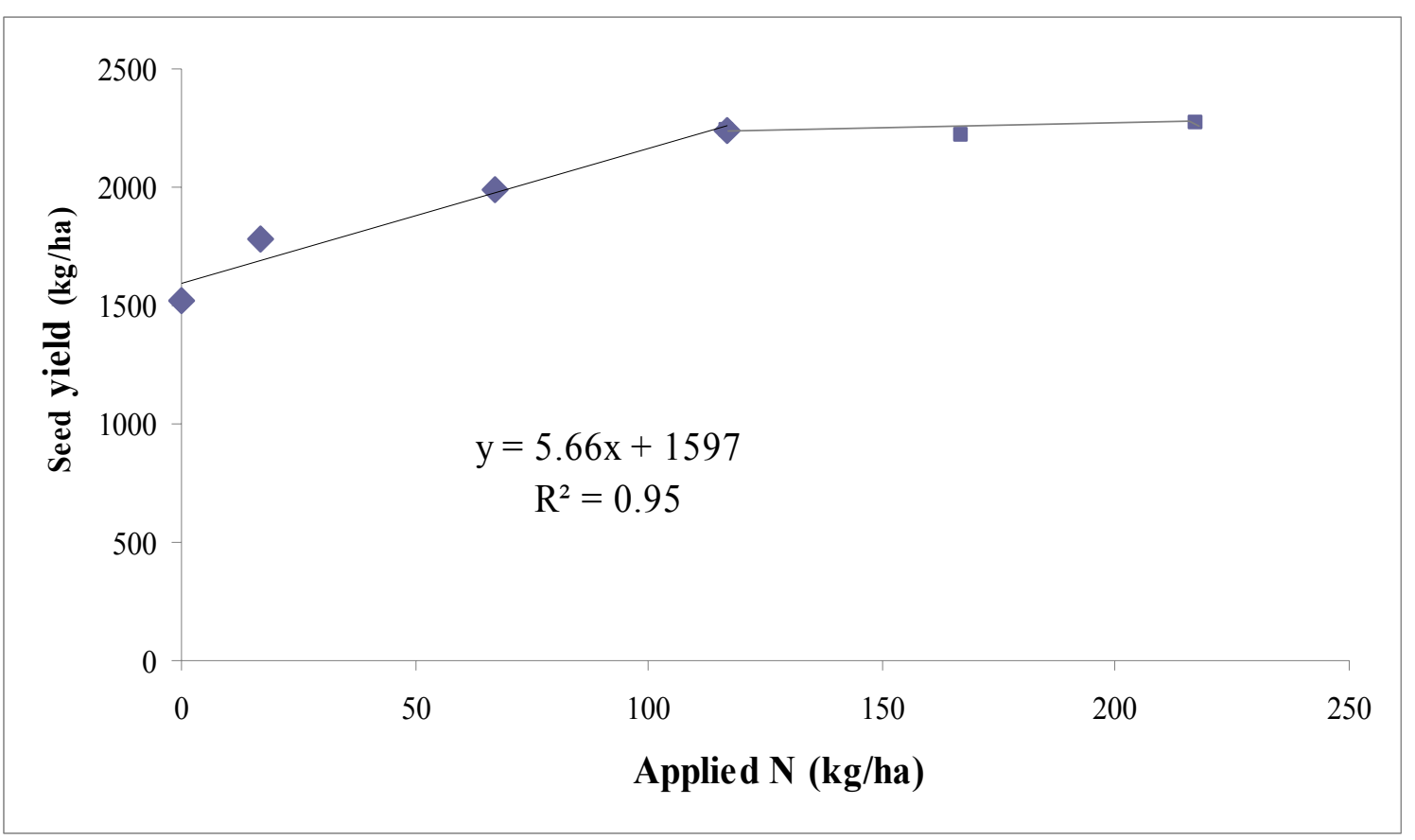

Figure 1 Linear-plateau applied seed yield response to N for Trial $12($ LSD 5\% $=202)$.

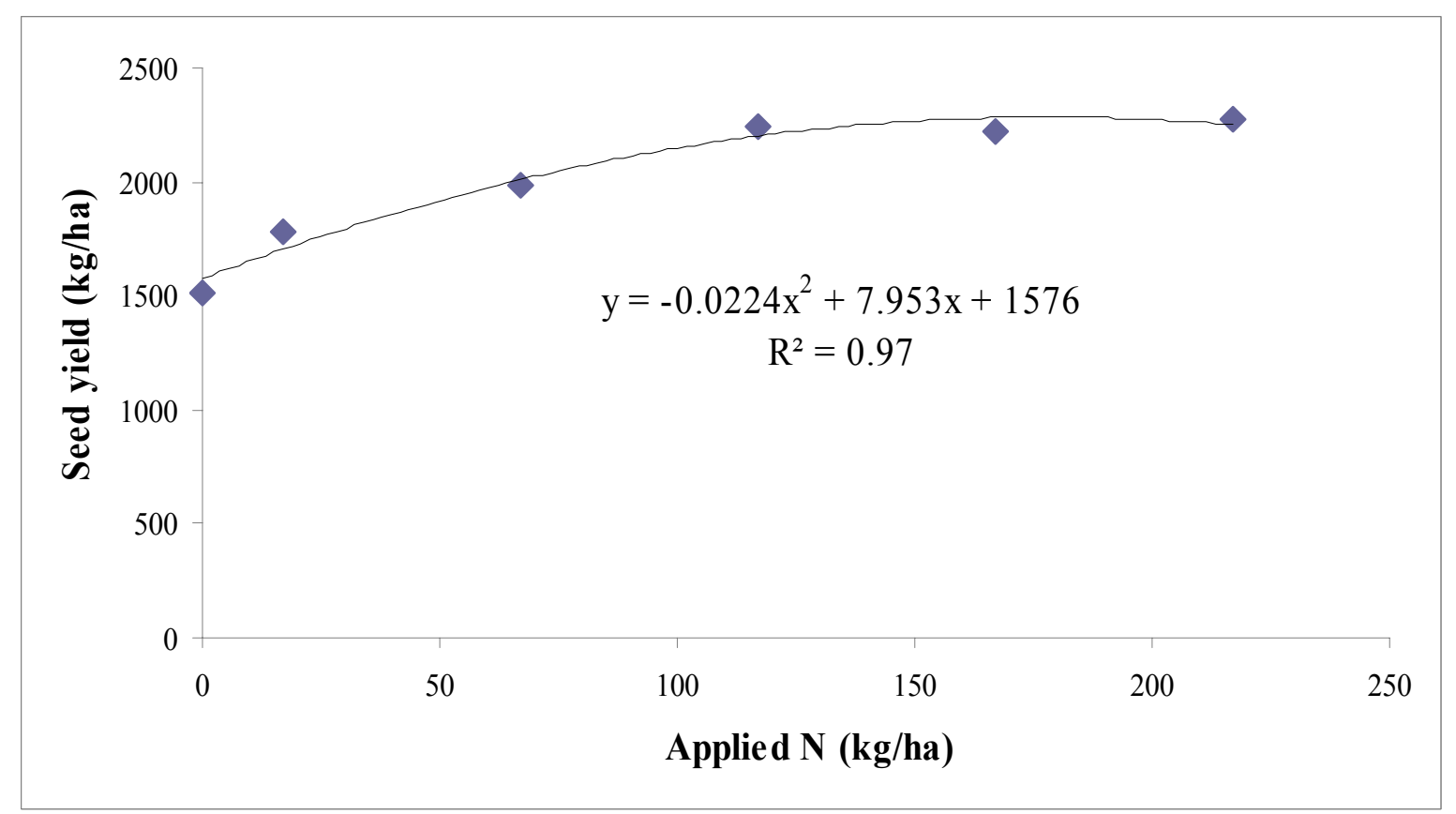

Figure 2 Polynomial model applied seed yield response to $\mathrm{N}$ for Trial 12. 
Table 2 Average and data range (kg N/ha) for 2003/07 trials for above ground biomass at optimum $\mathrm{N}$, total plant $\mathrm{N}$ (including roots), amount of soil $\mathrm{N}$ in above ground biomass of nil applied $\mathrm{N}$ treatments and total soil $\mathrm{N}$ (mineral + organic) $0-30 \mathrm{~cm}$.

\begin{tabular}{lll}
\hline & Average & Range \\
\hline N in above ground biomass & 192 & 159 to 280 \\
Total N in plant (assumed) & 232 & 199 to 320 \\
Total N in plant nil N & 93 & 44 to 141 \\
Total soil N & 5400 & 4190 to 8900 \\
\hline
\end{tabular}

\section{Plant uptake of $N$}

In the nil $\mathrm{N}$ treatments the average above ground plant uptake $\mathrm{N}$ was $93 \mathrm{~kg} \mathrm{~N} / \mathrm{ha}$ (Table 2) and the average soil mineral $\mathrm{N} / \mathrm{ha}$ was $41 \mathrm{~kg}$ (Table 1). The difference $(52 \mathrm{~kg}$ $\mathrm{N} / \mathrm{ha}$ ) in $\mathrm{N}$ uptake was from either deeper mineral $\mathrm{N}$ and/or from mineralisable $\mathrm{N}$ released during the growing season. At the optimum $\mathrm{N}$ rate above ground $\mathrm{N}$ uptake averaged $192 \mathrm{~kg} / \mathrm{ha}$ (Table 2). Based on published data (Cookson et al. 1999; Williams et al. 2001; Carbacick et al. 2003) roots in perennial ryegrass seed crops will have an estimated $40 \mathrm{~kg} \mathrm{~N} / \mathrm{ha}$; giving total plant $\mathrm{N}$ uptake of $232 \mathrm{~kg} / \mathrm{ha}$.

\section{Economic benefit and price sensitivity}

Using a linear-plateau model the $\mathrm{N}$ rate response in the linear phase averaged $3.7 \mathrm{~kg}$ seed per $\mathrm{kg}$ applied $\mathrm{N}$ with a range from 0.7 to 5.9 (Table 1). This equates to a $\$ 4.40$ return for every dollar invested in $\mathrm{N}$. The effect of $\mathrm{N}$ price variation on the sensitivity of optimum $\mathrm{N}$ rate was examined with a polynomial response and found to be insensitive to large price fluctuations as shown by Gislum et al. (2007). Calculating the optimum $\mathrm{N}$ rate for maximum economic treatment net benefit, using a polynomial model for trial 16 as an example, showed that increasing the price of $\mathrm{N}$ by $46 \%$ from $\$ 1.50$ (2007 price) to the current price of $\$ 2.20 / \mathrm{kg} \mathrm{N}$ lowered the economic optimum $\mathrm{N}$ from 167 to $160 \mathrm{~kg} \mathrm{~N} / \mathrm{ha}$. Increasing the price of seed shifted the optimum $\mathrm{N}$ to a slightly higher rate.

\section{Predicted applied $N$ rate}

In 2007 using preliminary data sets from Trials 1-13 (Table 1) we recommended that growers could predict their spring $\mathrm{N}$ from using the following simple calculator:

Spring applied $\mathrm{N}=200-$ mineral N (0$30 \mathrm{~cm})(\mathrm{kg} / \mathrm{ha})$

In 2008 this equation was tested against the 17 optimum applied $\mathrm{N}$ values calculated in Table 1. In 3 fields the predicted applied $\mathrm{N}$ was below the optimum; while in 7 trials the predicted applied $\mathrm{N}$ was correct and in the other 7 trials overestimated. The 200 model predicts an average applied $\mathrm{N}$ of $160 \mathrm{~kg} / \mathrm{ha}$ compared with the 17 trial average of 143 $\mathrm{kg} / \mathrm{ha}$. If the model is adjusted to a total optimum $\mathrm{N}$ requirement of $185 \mathrm{~kg} \mathrm{~N} /$ ha with $\mathrm{a} \pm 20 \mathrm{~kg} / \mathrm{ha}$ accuracy the model has the same number of under and over predictions but gives an average prediction of $143 \mathrm{~kg}$ applied N/ha, which is similar to the 17 trial average. Thus for spring 2008 our recommendation will be:

Spring applied $\mathrm{N}(\mathrm{kg} / \mathrm{ha})=185-$ mineral $\mathrm{N}$ $(0-30 \mathrm{~cm})(\mathrm{kg} / \mathrm{ha})$

\section{Discussion}

The trials predict that on average $145 \mathrm{~kg}$ applied N/ha is required for high yielding perennial ryegrass seed crops. Using late winter mineral $\mathrm{N}(0-30 \mathrm{~cm})$ values growers can predict their applied $\mathrm{N}$ rate using a total $\mathrm{N}$ requirement model of $185 \mathrm{~kg} \mathrm{~N} / \mathrm{ha}$. The data confirm that the average $\mathrm{N}$ rate on 30 
South Canterbury monitor perennial ryegrass crops during 2003/04 was too high. As a result of this research and associated extension activities the average $\mathrm{N}$ use rate on these monitor farms had declined to $150 \mathrm{~kg}$ applied $\mathrm{N}$ for the 2006/07 year. Total above ground plant uptake of $\mathrm{N}$ at the optimum applied $\mathrm{N}$ rate was higher than the amount of applied $\mathrm{N}$ by an average of $47 \mathrm{~kg} \mathrm{~N} /$ ha, i.e., perennial ryegrass is using at least $47 \mathrm{~kg}$ $\mathrm{N} /$ ha of soil $\mathrm{N}$ assuming $100 \%$ efficiency in uptake of applied $\mathrm{N}$.

Future work will focus on an improved understanding of $\mathrm{N}$ uptake with thermal time (canopy growth and development), growth stage and attempt to develop predictions of $\mathrm{N}$ requirement using early spring NDVI (normalised difference vegetative index) reflectance (Flowers et al. 2003).

\section{Acknowledgements}

The trials were funded by FAR (Foundation for Arable Research) using seed grower levy money. FAR also provided the Arable Site at Chertsey. We wish to thank the five seed growers who provided the trial sites - Eric Watson, Craige Mackenzie, Lindsay Read, Jonathan Clay, Nick Ward. Bill Archie (AgResearch Lincoln) and NZ Arable staff are thanked for technical support.

\section{References}

Ballance, 2008. South Island fertiliser prices effective 8 September 2008. Retrieved 10 October, 2008 from http://www.balance.co.nz

Brown, K.R. 1980a. Recent grass seed production studies in Canterbury. Herbage seed production. Grassland Research and Practice Series 1: 12-14.

Brown, K.R. 1980b. Seed production in New Zealand ryegrasses. New Zealand Journal of Experimental Agriculture 8: 33-39.

Carbacick, C.J.; Chastain, T.G.; Young 11l, W.C.; Silberstein, T.B. 2003. Root productivity and seed production in cool-season grasses. pp. 137-141 In:
Proceedings of the $5^{\text {th }}$ International Herbage Seed Conference.

Cookson, W.R.; Rowarth, J.S.; Cornforth, I.S.; Cameron, K.C. 1999. Sustainability issues involved with nitrogen fertilizer use in perennial ryegrass (Lolium perenne L.) seed crops. Journal of Applied Seed Production 17: 67-75.

Gislum, R.; Rolston, P.; Hart, J.M.; Chynoweth, R.; McCloy. B; Young III, W.C. 2007. Economical optimal nitrogen (ECO-N) application rate is all that matters to the growers. pp. 206-210. In: Seed production in the northern lights. Proceedings of the $6^{\text {th }}$ International Herbage Seed Conference.

Flowers, M.; Weisz, R.; Heiniger, R. 2003. Quantitative approaches for using color infrared photography for assessing in-season nitrogen status in winter wheat. Agronomy Journal 95: 1189-1200.

Hampton, J.G. 1987. Effects of nitrogen rate and timing of application on seed yield in perennial ryegrass cv. Grasslands Nui. New Zealand Journal of Experimental Agriculture 15: 9-16.

Hart, J.M.; Rolston, P.; Mellbye, M.E.; Silberstein, T.B.; Young III, W.C.; McCloy, B.L.; Gingrich, G.; Christensen, N.W.; Gilsum, R. 2007. Comparison of soil $\mathrm{N}$ tests for prediction of spring $\mathrm{N}$ rate in perennial ryegrass seed production. pp. 239-243. In: Seed production in the northern lights. Proceedings of the $6^{\text {th }}$ International Herbage Seed Conference.

Jamieson, P.D.; Armour, T.; Zyskowski, R. 2003. On-farm testing of the Sirius Wheat Calculator for $\mathrm{N}$ fertiliser and irrigation management. pp. 1-4. In: Solutions for a better environment. Proceedings of the $11^{\text {th }}$ Australian Agronomy Conference. 
MAF. 2006. Seed Certification 2005-2006 Field \& Laboratory Standards. AgriQuality Limited, Auckland, New Zealand. $80 \mathrm{pp}$.

McCloy, B.L.; Rolston, M.P. 2005. Nitrogen budgets in ryegrass seed crops 2004/05. Report to Foundation for Arable Research. FAR contract H04/05. 20 pp.

Payne, R.W.; Harding, S.A.; Murray, D.A.; Soutar, D.M.; Baird, D.B.; Welham, S.J.; Kane, A.F.; Gilmour, A.R.; Thompson, R.; Webster, R.; Tunnicliffe Wilson, G. (2007). The Guide to GenStat Release 10, Part 1: Syntax and Data Management. VSN International, Hemel Hempstead, United Kingdom.

Rolston, M.P.; McCloy, B.L.; Pyke, N.B. 2004. Grass seed yields increased with plant growth regulators and fungicides. Proceedings of the New Zealand Grassland Association 66: 127-132.
Rowarth, J.S.; Archie, W.J. 1995. A diagnostic method for prediction of seed yield in perennial ryegrass. pp. 64-67. In: Proceedings of the $3^{\text {rd }}$ International Herbage Seed Conference.

Rowarth, J.S.; Boelt, B.; Hampton, J.G.; Marshall, A.H.; Rolston, M.P.; Sicard, G.; Silberstein, T.B.; Sedcole, J.R.; Young, W.C. III 1998. The relationship between applied nitrogen concentrations in herbage and seed yield in perennial ryegrass (Lolium perenne L.) I. Grasslands Nui at five sites around the globe. Journal of Applied Seed Production 16: 105-114.

Williams, P.H.; Rowarth, J.S.; Tregurtha, R.J. 2001. Uptake and residual value of ${ }^{15} \mathrm{~N}$-labelled fertilizer applied to first and second year grass seed crops in New Zealand. Journal of Agriculture Science, Cambridge 137: 17-25. 